\title{
REGULATION OF GLYCOGENOLYSIS IN THE LOCUST FAT BODY DURING FLIGHT
}

\author{
W. J. A. van MarrewiJk, A. Th. M. van den Broek and A. M. Th. Beenakkers \\ Laboratory of Chemical Animal Physiology, State University of Utrecht, 8 Padualaan, \\ 3508 TB Utrecht, The Netherlands
}

(Received 27 February 1980; received for publication 2 June 1980)

\begin{abstract}
Glycogen reserves in the fat body of Locusta migratoria decrease dramatically during the first two hours of flight. In fat body of rested locusts only $10 \%$ of glycogen phosphorylase occurs in the active form. The enzyme is activated significantly during flight, when up to one-third of the total phosphorylase becomes active. Phosphorylase activation can also be accomplished by injection of corpus cardiacum extracts, to give a maximum of circa $75 \%$ active enzyme. Locust fat body is shown to contain protein kinase activity, which can be activated both by cyclic AMP and cyclic GMP. Apparent $K_{a}$-values are $0.13 \mu \mathrm{M}$ for cyclic AMP and $0.16 \mu \mathrm{M}$ for cyclic GMP. Results are discussed in relation to regulation of substrate utilization during flight.

Key Word Index: Locusta migratoria, fat body, glycogenolysis, phosphorylase, regulation, flight
\end{abstract}

\section{INTRODUCTION}

THAT carbohydrate is the main fuel during the initial flight period of locusts was first postulated by WeIsFOGH (1952). Recently VAN DER HORST et al. (1978a, b) substantiated and extended this by demonstrating that carbohydrate also contributes substantially to total energy supply during sustained flight (one quarter), the remaining three quarters being supplied by lipid.

In a number of insect species the rate of glycogenolysis has been shown to depend on the activity of glycogen phosphorylase (for review see SACKTOR, 1975). In the fat body of Periplaneta americana the enzyme is regulated by a hyperglycemic hormone from the corpora cardiaca (CC), apparently by conversion of inactive phosphorylase to the active form, resulting in an increased production of trehalose. Cyclic AMP could mimic this hormone action (STEELE, 1963, 1964). Activation of adenylate cyclase, enhanced cyclic AMP levels, and activation of cyclic AMP dependent protein kinase has been demonstrated to follow injection of CC-extracts (HANAOKA and TAKAHASHI, 1977, 1978; TAKAHASHI and HANAOKA, 1977). Thus, in $P$. americana cyclic AMP may act as a second messenger for the hyperglycemic hormone as it does for many vertebrate hormones.

As a part of this laboratory's investigation on the control of mobilization of substrates for insect flight the present paper deals with the regulation of glycogen phosphorylase in the locust fat body. The effect of flight and CC-extract on the activation of the enzyme was studied. In addition, protein kinase in the locust fat body was investigated.

\section{MATERIALS AND METHODS}

Migratory locusts, Locusta migratoria migratorioides, were reared under crowded conditions at $30^{\circ} \mathrm{C}, 40 \%$ r.h. and a photoperiod of $12 \mathrm{hr}$. The insects were fed with reed supplemented with rolled oats. Adult males, 12-14 days after imaginal ecdysis, were used in all experiments.

\section{Determination of glycogen phosphorylase activity}

Fat body extracts for measuring glycogen phosphorylase activities were prepared as follows. After cutting off the abdomen behind the first segment the head with the attached foregut was removed and the thorax immersed immediately in liquid nitrogen. The frozen thorax was opened from the ventral side and the fat body dissected free of adhering tissues. Fat bodies of four to five individuals were pooled in liquid nitrogen and homogenized in $2 \mathrm{ml}$ ice-cold $50 \mathrm{mM}$ phosphate buffer pH 7.0,5 mM EDTA, and $20 \mathrm{mM} \mathrm{NaF}$, using an ultra-Turrax disintegrator (Janke and Kunkel). The homogenate was centrifuged at $35,000 \mathrm{~g}$ for $15 \mathrm{~min}$ at $0^{\circ} \mathrm{C}$, and the infranatant between pelleted material and upper layer of fatty material used immediately for subsequent enzyme assay.

Glycogen phosphorylase activity was measured in the direction of glycogen breakdown according to the method of CHILDRESS and SACKTOR (1970). The assay system contained, in a volume of $1.0 \mathrm{ml}, 40 \mathrm{mM}$ phosphate buffer $\mathrm{pH} 7.0,5 \mathrm{mM}$ imidazol, $2 \mathrm{mM}$ EDTA, $1.4 \mathrm{mM}$ dithio-erythritol, $5 \mathrm{mM}$ magnesium acetate, $4 \mu \mathrm{M}$ glucose-1, 6 -diphosphate, $0.6 \mathrm{mM}$ NADP, $2 \mathrm{mg}$ of glycogen (free from AMP), 4 units of phosphoglucomutase, and 0.8 units of glucose-6-phosphate dehydrogenase. Reactions were started by the addition of fat body extract $(20-50 \mu \mathrm{l})$. Reduction of NADP was measured at $340 \mathrm{~nm}$ on a Zeiss PM-6 spectrophotometer. The assay was run at $25^{\circ} \mathrm{C}$. Active phosphorylase was assayed in the absence of AMP, whereas total phosphorylase activity was measured in the presence of $2 \mathrm{mM}$ AMP.

\section{Purification and assay of protein kinase}

Protein kinase from locust fat body was purified according to the method of KUO and GREENGard (1974). Pooled fat bodies of 50 individuals (about $8 \mathrm{~g}$ ) were homogenized (ultraTurrax disintegrator) with 5 vol. of $10 \mathrm{mM}$ potassium phosphate buffer pH 7.0, containing $4 \mathrm{mM}$ EDTA, $2 \mathrm{mM}$ mercaptoethanol, and $10 \mathrm{mM}$ magnesium acetate. The homogenate was centrifuged at $25,000 \mathrm{~g}$ for $30 \mathrm{~min}$ at $0^{\circ} \mathrm{C}$ and the infranatant fraction between pellet and upper layer of fatty material (the 'crude extract') removed and adjusted to $\mathrm{pH} 4.8$ with $1 \mathrm{M}$ acetic acid. The precipitated material was pelleted by centrifugation as before. The supernatant was then adjusted to $\mathrm{pH} 6.8$ with $1 \mathrm{M}$ potassium phosphate buffer $\mathrm{pH}$ 7.2. Solid ammonium sulphate was added to $50 \%$ saturation. The resultant precipitate was collected by centrifugation, dissolved in $2 \mathrm{ml}$ of the homogenization 
Tabie 1. Concentrations of free glucose and glycogen in the fat body of 12-14-day old male locusts, Locusta migratoria, during rest and after a $2 \mathrm{hr}$ flight period

\begin{tabular}{|c|c|c|c|c|}
\hline & \multicolumn{2}{|c|}{ Free glucose } & \multicolumn{2}{|l|}{ Glycogen } \\
\hline & $\mu$ moles. $\mathrm{g}^{-1}$ & $\mathrm{mg} \cdot \mathrm{g}^{-1}$ & $\mu$ moles glucosyl units. $\mathrm{g}^{-1}$ & $\mathrm{mg} \cdot \mathrm{g}^{-1}$ \\
\hline Rested & $0.29 \pm 0.14$ & $0.053 \pm 0.025$ & $117.90 \pm 26.47$ & $19.10 \pm 4.29$ \\
\hline Flown & $0.09 \pm 0.04$ & $0.016 \pm 0.007$ & $30.21 \pm 2.75$ & $4.89 \pm 0.45$ \\
\hline
\end{tabular}

Values represent the means \pm S.D. of ten (rested) or three (flown) pools of five animals each.

buffer and dialyzed overnight against the same buffer. After centrifugation the dialyzed solution was applied to a column $(1.4 \mathrm{~cm}$ i.d. $\times 10 \mathrm{~cm})$ of hydroxyapatite previously equilibrated with $10 \mathrm{mM}$ potassium phosphate buffer, $\mathrm{pH}$ 7.0. Protein was eluted from the column with a linear gradient of potassium phosphate buffer, $\mathrm{pH} 7.0(10-300 \mathrm{mM})$, in a total volume of $200 \mathrm{ml}$. Fractions of about $2.5 \mathrm{ml}$ were collected and assayed for protein kinase activity.

Protein kinase was assayed by the method of CoRBin and REIMANN (1974). The reaction mixture (100 $\mu$ l final volume) contained $50 \mathrm{mM}$ potassium phosphate buffer $\mathrm{pH} 7.0,10$ $\mathrm{mM}$ magnesium acetate, $0.1 \mathrm{mM}\left[\gamma^{-32} \mathrm{P}\right]$ ATP (The Radiochemical Centre, Amersham, U. K.) (100 dpm/pmole), $200 \mu \mathrm{g}$ of histone type II-A, $10 \mu \mathrm{M}$ cyclic AMP or cyclic GMP (when added), $20 \mu 1$ enzyme solution. For assays of tissue homogenates or crude extracts $20 \mathrm{mM} \mathrm{NaF}, 10 \mathrm{mM}$ theophylline, and $0.2 \mathrm{mM}$ EDTA were added. After incubation for $10 \mathrm{~min}$ at $30^{\circ} \mathrm{C}$, the reaction was terminated by transferring a $50 \mu \mathrm{l}$ sample onto Whatman 3-MM filter paper $(2 \times 2 \mathrm{~cm})$ and immediately immersing the paper in ice-cold $10 \%(\mathrm{w} / \mathrm{v})$ trichloroacetic acid. The papers were washed and dried with, respectively, $5 \%$ trichloroacetic acid, $96 \%$ ethanol and diethyl ether. The dried papers were placed into minivials with $5 \mathrm{ml}$ of a scintillant (Insta-Fluor II, Packard) and radioactivities were counted in a Packard Model 2420 liquid scintillation spectrometer. One unit of enzyme activity was that amount catalyzing the transfer of 1 pmole of phosphate from $\left[{ }^{32} \mathrm{P}\right]$ ATP to histone in $5 \mathrm{~min}$ at $30^{\circ} \mathrm{C}$.

\section{Determinations of glycogen and protein}

Fat body glycogen was determined spectrophotometrically after enzymatic hydrolysis with amyloglucosidase, as described by KEPPLER and DECKER (1974).
Protein concentration was measured by the method of SChackTerle and Pollack (1973). Bovine serum albumine (Fluka AG, Buchs, Switzerland) was used as a standard.

\section{Other methods}

Flight experiments were performed on a motor-driven roundabout as described by VAN DER HORST et al. (1978a). Extracts of the corpora cardiaca were prepared and injected according to HoLwERDA et al. (1977).

\section{RESULTS}

In order to establish the rate of utilization of carbohydrate reserves from the fat body during flight the concentrations of glycogen and free glucose were determined in fat bodies of rested and flown locusts (Table 1). During flight fat body glycogen decreased dramatically. After a $2 \mathrm{hr}$ flight period only $25 \%$ of the glycogen reserves present in rested locusts was left. The concentration of free glucose in the locust fat body was very low, but also decreased substantially during flight.

Since glycogen phosphorylase is the rate-limiting enzyme in glycogenolysis, its regulation was investigated in the locust fat body. In Fig. 1 the effect of flight on the activation state of glycogen phosphorylase is shown. Flight resulted in an increased activity of glycogen phosphorylase. A significant regression of the percentage phosphorylase in the active form on flight time was found $(P<0.005)$.

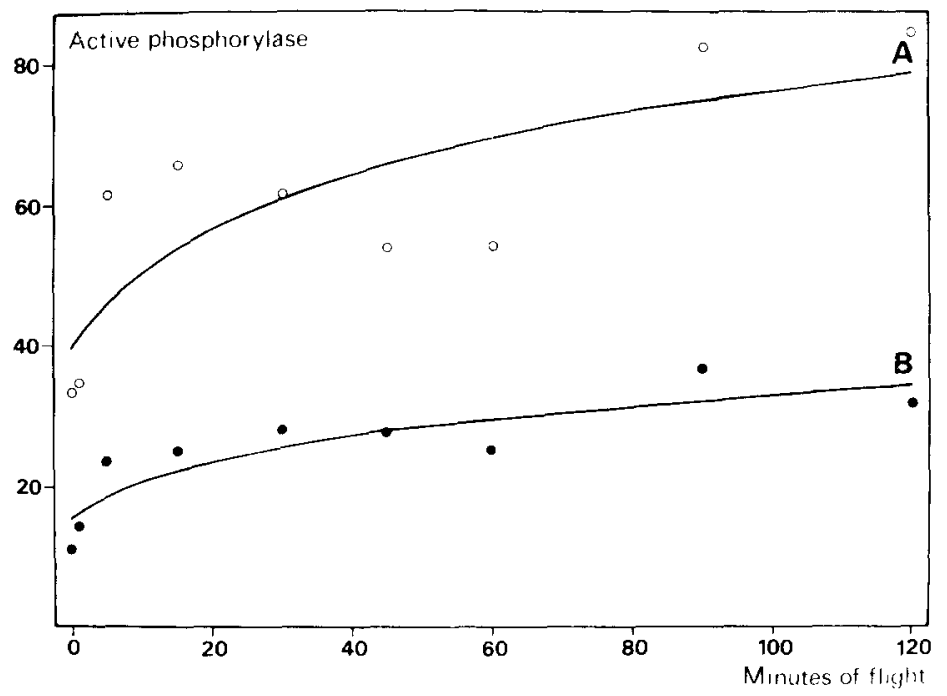

Fig. 1. Effect of flight activity on glycogen phosphorylase in the fat body of Locusta migratoria. A (O), increase of active phosphorylase specific activity (nmole G-1-P formed.min ${ }^{-1} \cdot \mathrm{mg} \mathrm{protein}^{-1}$ ) during flight, represented by the regression equation: $y=35.34 \log (X+10)+4.48 ; \mathrm{B}(\bullet)$, increase of active phosphorylase as a percentage of total phosphorylase during flight, represented by the regression equation: $y=16.74 \log$ $(X+10)-0.96$. Each value is the mean of four or five groups of locusts. 


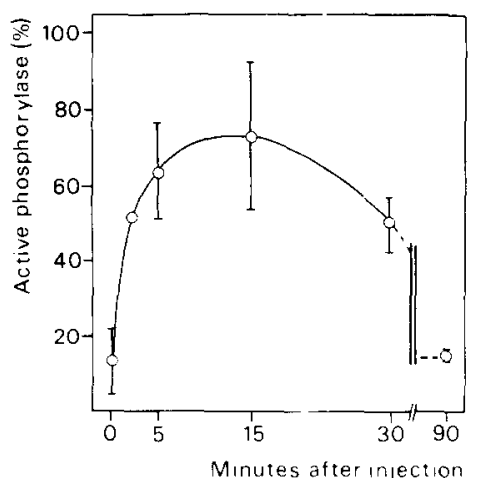

Fig. 2. Activation of glycogen phosphorylase in the locust fat body at different periods after injection of corpus cardiacum extracts ( 0.1 pair $\mathrm{CC}$-equivalents per locust). Values are the means $\pm S$. D. of four or five groups of five animals each (except the value after $2 \mathrm{~min}$, which is the mean of two groups).

There was also a significant regression of the specific activity of active phosphorylase on flight time $(P<0.01)$.

Next the activation of glycogen phosphorylase as observed during flight was investigated to see whether it could be induced by corpora cardiaca (CC). Locusts were injected with a CC-extract and fat body phosphorylase was assayed at specific times after the injection. Figure 2 shows a rapid activation of the enzyme upon injection of 0.1 pair CC-equivalents, resulting in more than $50 \%$ active phosphorylase already after a 2 min incubation period. The highest activation, $75 \%$ of total phosphorylase in the active form, was reached $15 \mathrm{~min}$ after injection. Thereafter the activation state returned gradually to its zero time level. Distilled water, when injected instead of CC-extract, did not induce activation of phosphorylase.

The purification of fat body protein kinase obtained in successive purification steps is reported in Table 2. After the final chromatography on hydroxyapatite a hundredfold increase in specific enzyme activity was obtained. The protein kinase was eluted at about 0.1 $\mathrm{M}$ phosphate (Fig. 3). Enzyme activity is relatively low in the absence of cyclic nucleotide, but is strongly activated by $10^{-5} \mathrm{M}$ cyclic AMP and $10^{-5} \mathrm{M}$ cyclic GMP. In order to determine more precisely the cyclic nucleotide dependence of the fat body protein kinase, the purified enzyme (fractions 32-35, see Fig. 3) was assayed in the presence of various concentrations of cyclic nucleotides. Figure 4 shows that with cyclic

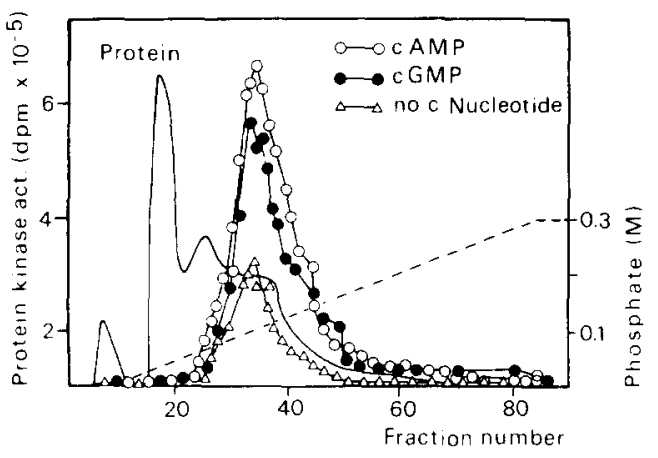

Fig. 3. Chromatography of protein kinase from locust fat body. The $\left(\mathrm{NH}_{4}\right)_{2} \mathrm{SO}_{4}$ precipitate ( $c f$. Table 2 ) was eluted from a column $(1.4 \mathrm{~cm}$ i.d. $\times 10 \mathrm{~cm})$ of hydroxyapatite with a linear phosphate gradient $(0.01-0.3 \mathrm{M}$, total volume $200 \mathrm{ml})$ and fractions $(2.6 \mathrm{ml})$ were assayed for protein kinase in the presence and the absence of cyclic nucleotides. 'Protein' represents the adsorbance at $280 \mathrm{~nm}$.

AMP the maximal activation of the enzyme is higher than with cyclic GMP, and is reached at a lower nucleotide concentration. However, the apparent $K_{a}$-values are nearly identical for both nucleotides: $0.13 \mu \mathrm{M}$ for cyclic AMP and $0.16 \mu \mathrm{M}$ for cyclic GMP.

\section{DISCUSSION}

The carbohydrate content of the fat body of L. migratoria decreases during flight. These carbohydrate reserves can be depleted totally, as no

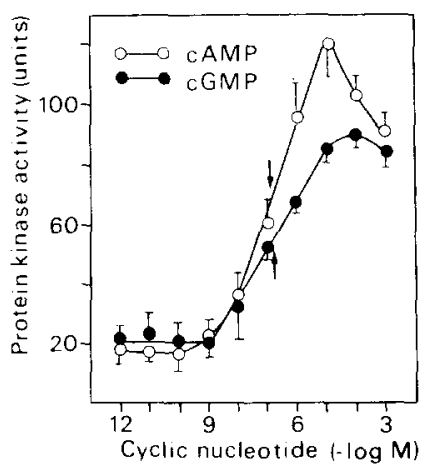

Fig. 4. Activity of partially purified protein kinase from locust fat body (fractions 32-35, cf. Fig. 3 and Table 2) in the presence of varying concentrations of cyclic nucleotides. At each concentration the mean and SD of three determinations are given. Arrows indicate apparent $\mathrm{K}_{\mathrm{a}}$-values.

Table 2. Extraction of protein kinase from locust fat body. The enzyme was assayed in the presence of $0.5 \mu \mathrm{M}$ cyclic AMP

\begin{tabular}{lccc}
\hline & $\begin{array}{c}\text { Enzyme specific activity } \\
\text { (units/mg protein) }\end{array}$ & $\begin{array}{c}\text { Purification } \\
(\times \text {-fold) }\end{array}$ \\
\hline Homogenate & b, & 105 & 1 \\
Crude extract & b, & 410 & 4 \\
pH 4.8 supernatant & b, & 850 & 8 \\
$\left(\mathrm{NH}_{4}\right)_{2} \mathrm{SO}_{4}$ precipitate & b, & 1180 & 11 \\
$\mathrm{Hydroxyapatite} \mathrm{eluate} \mathrm{(see} \mathrm{Fig.} \mathrm{3)}_{\text {- whole peak (fractions 24-53) }}$ & b, $\quad 6100$ & 58 \\
$-\quad$ top of peak (fractions 32-35) & b, 11,070 & 105 \\
\hline
\end{tabular}


carbohydrate can be detected when locusts are flown overnight (TIETZ, 1965). The glycogen concentration in the fat body of our experimental animals amounted to about $2 \mathrm{mg}$ per $100 \mathrm{mg}$ fresh tissue in rested locusts. After a $2 \mathrm{hr}$ flight only $25 \%$ was left. The flight muscles of $L$. migratoria contain only a small amount of glycogen, less than $0.5 \mathrm{mg}$ per $100 \mathrm{mg}$ fresh tissue, from which about $0.2 \mathrm{mg}$ is used during a $2 \mathrm{hr}$ flight period (WORM and BEENAKKERS, 1980). Thus, in this locust the major part of the glycogen as a fuel for flight is derived from the fat body. In contrast, the fat body of the cockroach $P$. americana, provides only $9 \%$ of the total glycogen that is consumed during flight, while $91 \%$ is supplied by the thoracic muscles (DOWNER and PARKer, 1979).

Our results clearly demonstrate that in the locust during flight the breakdown of fat body glycogen is stimulated by an activation of glycogen phosphorylase. Although this activation starts immediately after the onset of flight there is, however, no appreciable influx of trehalose into the haemolymph during the first $30 \mathrm{~min}$ of flight, as VAN DER HORST et al. (1978b) showed a constancy of the specific radioactivity of the labelled haemolymph trehalose pool during this period. This might implicate a temporary accumulation of trehalose in the fat body or more likely of its precursors derived from glycogen during this period, as according to APPLEBAUM and SCHLESINGER (1973) no appreciable amount of trehalose accumulates in the locust fat body. In this first flight period the trehalose which is consumed by the flight muscles is mainly derived from haemolymph stores.

From the decrease of the glycogen concentration in the fat body during flight it is calculated that the rate of glycogen consumption corresponds with $8.8 \mu$ mole glucose-1-phosphate (G-1-P)/hr per locust. The rate of trehalose utilization during steady state conditions, reached after $30 \mathrm{~min}$ of flight, is $2.4 \mathrm{mg}$ trehalose $/ \mathrm{hr}$ per locust (VAN DER HORST et al., 1978b), corresponding to $14.0 \mu$ mole G-1-P/hr. Hence there will be a sufficient amount of fat body glycogen to supply $63 \%$ of the trehalose consumed during the steady state. If this supply is assumed to remain constant until the store is totally depleted, fat body glycogen reserves will be sufficient to maintain their contribution of $63 \%$ for a period of $2 \mathrm{hr}$, which as indicated, begins after half an hour of flight. It seems, however, that because the calculated rate of glycogen consumption is an average value for the period between 30 and 120 min of flight, the contribution of fat body glycogen is greater than $63 \%$ in the beginning, decreasing along with depletion of the glycogen reserves. Thus, other sources will also contribute trehalose to the flight muscles, although the phosphorylase capacity in fat body of $15.6 \mu$ mole G-1-P formed/hr per locust ( $\sim 60$ nmole G-1-P/min per $\mathrm{mg}$ protein) meets total trehalose synthesis needed during prolonged flight.

The present study shows that glycogen phosphorylase activity in the fat body of $L$. migratoria is regulated by a factor from the corpora cardiaca. A similar regulatory effect of the $\mathrm{CC}$ on fat body phosphorylase was demonstrated in the cockroach P. americana (STEELE, 1963, 1964) and Leucophaea maderae (WIENS and GiLberT, 1967a). In contrast, in the silkmoth Hyalophora cecropia, CC-extracts were without effect on fat body phosphorylase (WIENS and GILBERT, 1967b). Cockroach CC contain a hyperglycemic hormone which raises haemolymph trehalose level. Although locust $\mathrm{CC}$, when injected in $P$. americana, elicit a hyperglycemic response, in L. migratoria itself no appreciable hyperglycemia occurs, in spite of the activation of the fat body phosphorylase. Apparently release of trehalose from the fat body does not start before the haemolymph trehalose level has become sufficiently low, as is the case after a 30 min flight. Our results, showing a low percentage of active phosphorylase in control animals and a nearly sixfold increase after CC-injection, disagree with those of GolDSwORTHY (1970). He showed an age-dependent activation of fat body phosphorylase in male $L$. migratoria, starting with no less than $45 \%$ in the active form one day after the final ecdysis and reaching a constant level of $70-75 \%$ active enzyme twelve days later. Further activation by CC-extracts was demonstrated only in one-to three-day-old adult locusts, and a high dose (1.0 pair CC-equivalents) was required for $70 \%$ activation.

The possible intermediary role of protein kinase in the regulation of glycogen phosphorylase, which seems to be the case in $P$. americana (TAKAHASHI and HANAOKA, 1977), led to the present study of this enzyme in locust fat body. Although cyclic AMP was a somewhat better activator than cyclic GMP, protein kinase showed no absolute specificity for either nucleotide. Injection of CC-extract or purified adipokinetic hormone as well as flight activity evoke an increase in cyclic AMP concentration in locust fat body, but also elevate the diglyceride level in the haemolymph (GÄDE and HoLWERDA, 1976; SPENCER and CANDY, 1976; GÄDE, 1979). Therefore, it remains to be established whether the cyclic nucleotide activated protein kinase system is involved in the regulation of glycogen breakdown during flight, or in the release of diglyceride from the fat body. A role in both metabolic processes cannot be ruled out, as it was shown that in rat adipose tissue phosphorylase activity and lipolysis could be activated independently, even though both responses were mediated by cyclic AMP dependent protein kinase (HoNEYMAN et al., 1979).

Although a regulatory role for the $\mathrm{CC}$ on glycogen phosphorylase is established, the nature of the phosphorylase activating factor in L. migratoria is actually unknown. MORDUE and GOLDSWORTHY (1969) and GolDswORTHY (1970) have shown that the glandular lobe of the $\mathrm{CC}$ is more potent than the storage lobe in elevating the active phosphorylase levels in locust fat body. According to Downer (1979a,b) at least two hyperglycemic ("hypertrehalosemic') effectors are present in the neuroendocrine system of $P$. americana: the hyperglycemic hormone present in the $\mathrm{CC}$ and the neurotransmitter octopamine. The marked glycogenolytic effect of octopamine on cockroach fat body would result from the same mechanism as described for nerve cord tissue (ROBERTSON and STEELE, 1972), i. e. activation of glycogen phosphorylase mediated by activation of an octopamine-sensitive adenylate cyclase. The presence of high concentrations of octopamine has also been demonstrated in locusts: in the brain of Schistocerca gregaria (ROBERTSON, 1976) 
and in the nervous system and glandular parts of the CC of L. migratoria (DAVID and LAFON-CAZAL, 1979). A possible role of this biogenic amine in the regulation of substrate mobilization for locust flight will be investigated.

Acknowledgements - The authors are indebted to Mr. H. HoolJKaAs and Mr. M. J. M. Koolen for their technical assistance and to Mr. M. DE WAAL for his valuable advice on statistical analysis of data.

\section{REFERENCES}

Applebaum S. W. and Schlesinger H. M. (1973) Regulation of locust fat-body phosphorylase. Biochem. J. 135, 37-41.

Childress C. C. and SACKTOR B. (1970) Regulation of glycogen metabolism in insect flight muscle. Purification and properties of phosphorylase in vitro and in vivo. J. biol. Chem. 245, 2927-2936.

Corbin J. D. and Reimann E. M. (1974) Assay of cyclic AMP-dependent protein kinases. In Methods in Enzymology (Ed. by Colowick S. P. and KAPLAN N. O.) Vol. 38, pp. 287-290. Academic Press, New York.

David J. C. and Lafon-Cazal M. (1979) Octopamine distribution in the Locusta migratoria nervous and nonnervous systems. Comp. Biochem. Physiol. 64C, 161-164.

DOWNER R. G. H. (1979a) Induction of hypertrehalosemia by excitation in Periplaneta americana. J. Insect Physiol. 25, 59-63.

DOWNER R. G. H. (1979b) Trehalose production in isolated fat body of the American cockroach, Periplaneta americana. Comp. Biochem. Physiol. 62C, 31-34.

Downer R. G. H. and PARKeR G. H. (1979) Glycogen utilization during flight in the American cockroach, Priplaneta americana L. Comp. Biochem. Physiol. 64A, 29-32.

GäDE G. (1979) Studies on the influence of synthetic adipokinetic hormone and some analogs on cyclic AMP levels in different arthropod systems. Gen. comp. Endocr. 37, 122-130.

GäDE G. and Holwerda D. A. (1976) Involvement of adenosine $3^{\prime}: 5^{\prime}$-cyclic monophosphate in lipid mobilization in Locusta migratoria. Insect Biochem. 6 , 535-541.

GolDSwORTHY G. J. (1970) The action of hyperglycaemic factors from the corpus cardiacum of Locusta migratoria on glycogen phosphorylase. Gen. comp. Endocr. 14, 78-85.

HANAOKA K. and TAKahashi S. Y. (1977) Adenylate cyclase system and the hyperglycemic factor in the cockroach, Periplaneta americana. Insect Biochem. 7, 95-99.

HANAOKA K. and TAKaHASHI S. Y. (1978) Control of carbohydrate metabolism including the mechanism of action of the hyperglycemic hormone in insects. In Comparative Endocrinology (Ed. by GAILlARD P. J. and BOER H. H.), pp. 455-458. Elsevier/North-Holland Biomedical Press, Amsterdam.

Holwerda D. A., VAN Doorn J. M. and Beenakkers A. M. TH. (1977) Characterization of the adipokinetic and hyperglycaemic substances from the locust corpus cardiacum. Insect Biochem. 7, 151-157.

Honeyman T. W., Levy L. K. and Goodman H. M. (1979)
Independent regulation of phosphorylase and lipolysis in adipose tissue. Am. J. Physiol. 6, E11-E17.

KEPPLER D. and DECKER K. (1974) Glycogen determination with amyloglucosidase. In Methods of Enzymatic Analysis (Ed. by BergMeYer H.) Vol. 3, pp. 1127-1131. Academic Press, New York.

Kuo J. F. and Greengard P. (1974) Purification and characterization of cyclic GMP-dependent protein kinases. In Methods in Enzymology (Ed. by CoLowick S. P. and KaPlan N. O.) Vol. 38, pp. 329-350. Academic Press, New York.

Mordue W. and Goldsworthy G. J. (1969) The physiological effects of corpus cardiacum extracts in locusts. Gen. comp. Endocr. 12, 360-369.

Robertson H. A. (1976) Octopamine, dopamine and noradrenaline content of the brain of the locust, Schistocerca gregaria. Experientia 32, 552-554.

RoBERTSON H. A. and STEELE J. E. (1972) Activation of insect nerve cord phosphorylase by octopamine and adenosine 3', 5'-monophosphate. J. Neurochem. 19, 1603-1606.

SACKTOR B. (1975) Biochemistry of insect flight. Utilization of fuels by muscle. In Insect Biochemistry and Function (Ed. by CANDY D. J. and Kilby B. A.) pp. 1-88. Chapman \& Hall, Lundon.

SChackterle G. R. and Pollack R. L. (1973) A simplified method for the quantitative assay of small amounts of protein in biological material. Anal. Biochem. 51, 654-655.

SPENCER J. M. and CANDY D. J. (1976) Hormonal control of diacyl glycerol mobilization from fat body of the desert locust, Schistocerca gregaria. Insect Biochem. 6, 289-296.

STEELE J. E. (1963) The site of action of insect hyperglycemic hormone. Gen. comp. Endocr. 3, 46-52.

STEELE J. E. (1964) The activation of phosphorylase in an insect by adenosine $3^{\prime}, 5^{\prime}$-phosphate and other agents. $\mathrm{Am}$. Zool. 4, 328

Takahashi S. Y. and Hanaoka K. (1977) Multiple protein kinases in the American cockroach, Periplaneta americana. Insect Biochem. 7, 133-139.

TiETz A. (1965) Metabolic pathways in the insect fat body. In Handbook of Physiology (Ed. by ReNALD A. E. and CAHILI C. F. JR.) Vol. 5, pp. 45-54. Williams \& Wilkins, Baltimore.

Van Der Horst D. J., Baljet A. M. C., Beenakkers A. M. TH. and van Handel E. (1978a) Turnover of locust haemolymph diglycerides during flight and rest. Insect Biochem. 8, 369-373.

VAN DER Horst D. J., Van DoORn J. M. and BeEnaKkers A. M. TH. (1978b) Dynamics in the haemolymph trehalose pool during flight of the locust, Locusta migratoria. Insect Biochem. 8, 413-416.

WeIs-FoGH T. (1952) Fat combustion and metabolic rate of flying locusts (Schistocerca gregaria Forsk). Phil. Trans. R. Soc. (B) 237, 1-36.

Wiens A. W. and Gilbert L. I. (1967a) Regulation of carbohydrate mobilization and utilization in Leucophaea maderae. J. Insect Physiol. 13, 779-794.

Wiens A. W. and Gilbert L. I. (1967b) The phosphorylase system of the silkmoth, Hyalophora cecropia. Comp. Biochem. Physiol. 21, 145-159.

Worm R. A. A. and Beenakkers A. M. Th. (1980) Regulation of substrate utilization in the flight muscle of the locust, Locusta migratoria, during flight. Insect Biochem. 10, 53-59. 